To cite this article: Austin J. C. Mole \& Nelson Edewor (2020) Challenges Associated with Postgraduate Students' Awareness and Use of Online Journals in Nigerian Universities. Information Impact: Journal of Information and Knowledge Management, 11:1, 16-24, DOI: dx.doi.org/10.4314/iijikm.v11i1.2

To link to this article: https://doi.org/10.4314/iijikm.v11i1.2

\title{
Challenges Associated with Postgraduate Students' Awareness and Use of Online Journals in Nigerian Universities
}

\author{
${ }^{1}$ Austin J. C Mole and ${ }^{2}$ Nelson Edewor \\ ${ }^{1}$ Department of Library and Information Science, University of Nigeria, Nsukka \\ ${ }^{2}$ University Library Federal University of Petroleum Resources, Effurun
}

\begin{abstract}
This study investigates the challenges associated with postgraduate students' awareness and use of online journals in Nigerian universities. The study adopted the descriptive survey design. The population of the study comprised 10, 775 registered postgraduate students in federal and state universities in south-south zone of Nigeria. Based on the Krejcie and Morgan sample size determination table, a sample size of 370 postgraduate students were chosen for the study. The questionnaire was the instrument used for data collection. Copies of the questionnaire were distributed by hand by the researchers with the help of research assistants. Mean and standard deviation were used to analyse the data from the questionnaire. The major findings challenges associated with postgraduate students' awareness and use of online journals were identified to include absence of enlightenment on online journals by lecturers $(\bar{X} 2.94, \mathrm{SD}=.87)$, lack of knowledge of publishers of online journals $(\bar{X} 2.67, \mathrm{SD}=.98)$, lack of user education on online journals from university libraries $(\bar{X} 2.80, \mathrm{SD}=.93)$, inadequate computer systems in university libraries $(\bar{X} 3.58, \mathrm{SD}=.73)$, frequent power outages in libraries $(\bar{X} 3.48, \mathrm{SD}=.66)$, and slow internet connectivity in university libraries $(\bar{X} 2.96, \mathrm{SD}=.94)$ among others. Respondents in the study proffered several strategies for enhancing awareness and use of online journals. Based on the findings, it was recommended that the cost of data bundle should be reduced by Internet service providers, particularly for postgraduate students to enhance the use of online journals. University libraries should engage in aggressive awareness campaign on online journals and their usefulness for effective research in universities. Additionally, university libraries should create a database of open access online journals to enable users search full text articles online from various publishers.
\end{abstract}

Keywords Online Journals, Awareness, Use, Universities, Challenges

CONTACT Austin. J. C. Mole and Nelson Edewor nelson.edewor@fupre.edu.ng Department of Library and Information Science, University of Nigeria, Nsukka and University Library, Federal University of Petroleum Resources Effurun, Nigeria 2020 The Authors Published with License by Information Impact 


\section{Introduction}

Postgraduate students undertake postgraduate studies for the purpose of enhancing their career or educational status. Some postgraduate students pursue higher degrees as job requirement condition. Thus, their continued existence and upgrade in their job is predicated on the possession of higher degrees. It is a general rule to have completed a bachelor's degree or its equivalents before pursuing a postgraduate degree. The postgraduate student undertakes a scholarly research journey under the supervisory guidance of a very senior academic in a particular department. The main role of the supervisor is to provide advice at every stage of the research (Agu \& Oluwatayo, 2013).

Research is a major component of postgraduate education. Postgraduate research activities are facilitated by a variety of information materials, including journals. According to Reitz (2004) journals are professional publications devoted to disseminating original researches and commentaries on current developments within a specific discipline, sub-discipline or field of study. The advent of Information and Communication Technology and Internet Technology has brought about the development of online journals. According to Panda and Mohanta (2008), an online journal is any journal magazine, newsletter or serial publication available over the Internet in electronic format. A journal can be called an online journal if its content are produced and stored in electronic form and its contents can be scanned in a database and retrieved online (Ali \& Nisha, 2011). Online journals are therefore, scholarly publications, published online, and can only be accessed with computer networks and the Internet.

Online journals are considered very important for postgraduate research, because they provide very current update/information in a particular field. Postgraduate students prefer online journals to the print version for research activities, the reason being ease of use, quick to access, easily searched and information can be saved and manipulated. In addition, the print journal publishing process makes it difficult to access very current information in a particular field as in some cases, before the print journal is published, information contained therein is outdated. The use of online journals is to help postgraduate research/researchers in enriching their literature review and finding new developments in their fields, hence the importance of online journals for postgraduate research cannot be overemphasized. Recognizing this fact, libraries worldwide are transitioning from using print predominantly to using both print and electronic resources. In some libraries, subscriptions to print journals have been cancelled (England, 2013). There is no doubt that library and information service provision has gone beyond the four walls of the traditional library system. Library and information service delivery has moved into the virtual space where access and use is real time and highly interactive. With advances in ICT and e-publishing, access to full text online journals has become commonplace (Sharma, 2009).

There is no gainsaying the fact that the use of online journals among postgraduate students is increasing and that they are making fewer library visits (Borego, 2010). This is not without challenges. Despite the importance of online journals for postgraduate research, there are some challenges associated with their awareness and use. This is the crux of this study. In addition, there is dearth of empirical data on challenges associated with awareness and use of online journals among postgraduate students of Nigerian universities. Much that has been written centred largely on the whole gamut of electronic information resources. There appears to be a dearth of any known study on challenges associated with awareness and use of online journals among postgraduate students in Nigeria. it is in this context, that this study seeks to investigate the challenges associated with awareness and use of online journals among postgraduate students' of universities in Nigeria.

\section{Objective of the study}

The main objective of the study is to investigate the challenges associated with awareness and use of online journals among postgraduate students of universities south-south Nigeria. Specifically, the objectives of the study include to: 
- Identify the challenges associated with postgraduate students' awareness and use of online journals.

- Determine strategies for enhancing the postgraduate students' awareness and use of online journals in university libraries in Nigeria.

\section{Research questions}

- what are the challenges associated with postgraduate students' awareness and use of online journals for effective research in universities in Nigeria?

- what are the strategies for enhancing the postgraduate students' awareness and use of online journals in university libraries in Nigeria?

\section{Literature review}

In spite of the numerous benefits derived from the use of online journals, there are some challenges which have helped to reconceptualise scholarship. The development of online journals poses some challenges. Some of these problems are cost constraints, infrastructural/technical issues, users' computer skills, inter library loan constraints and limited access to PCs.

Subscription to online journals is capital intensive, so institution libraries and individuals may not be able to fund, sustain and renew their subscription. England (2013) pointed out that the cost of online journals is high, especially as they are subject to VAT. She added that after initial subscription, further renewal and access are areas of further expenditure. Though open access platforms are available, a lot of professional journals are fee based. Anckar and Walden (2001) identified lack of financial resources as one of the most important barrier inhibiting institutions/libraries from subscribing to online journals. As a result of this, not all libraries have funds to subscribe to professional online journals. Even after, initial subscription, areas of further expenditure include, renewal fees, purchase and maintenance of systems, networking expenses and even replacement of faulty systems. Also poor funding to attract skilled human resources to install and manage online technology to access online journals constitute a problem too.

Another problem associated with the use of online journals is infrastructural/technical issue. This is even more pronounced in developing countries. Gbaje (2007) maintains that bandwidth connectivity is very slow and erratic to support the downloading of electronic resources. Slow download speed has been identified as one of the problems associated with the use of online journals (Thong, Hong \& Tam, 2004). Slow Internet connection is a problem hindering access and use of online journals. According to Manda (2005), slow internet connectivity has always generated a lot of complaints, which makes access to online journals difficult and uninteresting. Other technical issues are 'loss of content if journal changes publishers', 'loss of access without notice due to technical problems on the publishers' server' (England, 2013). These technical problems can be frustrating, resulting in loss of interest and enthusiasm for online journals. Again, online journals rely solely on electricity power supply to function. Omekwu (2004) added that the epileptic power supply causes serious damage to computer hardware, resulting in crashing of huge online journal databases. Suffice to note that frequent power outages remain a big problem in Nigeria. Therefore access to online journals can be hindered, either at home, libraries, offices etc. Our handheld mobile devices depend on electricity to be fully charged to be able to access online journals. On the whole, the cost of running power generating plants is unbearable.

The level of computer skills is a correlate to effective use of online journals. Gakibayo et al (2013:17) argue that " lack of retrieval skills and computer skills limit students ability to effectively access online journals'. To fully, take advantage of the potentials online journals have to offer, postgraduate students need to be fully immersed in the associated technologies. There is no doubt that computer skills, information literacy skills, among others, are required to navigate the Internet and 
retrieve relevant information. The use of online journal is largely depend on the users' ability to navigate the Internet. Although, the actual process of searching a database for information is done by the computer, some intellectual effort in searching and analyzing queries is required on the part of the user. According to Nwalo (2000), impromptu quick reference searching is highly language dependent; so much attention has to be paid to terminology. Technical vocabulary must be fully understood by the user.

The introduction of ICT and the emergence of relevant new ICT in the library and information profession have led to fundamental, significant and fast paced changes in the way and manner library services are offered. With the advent of ICT, library and information service delivery have gone virtual. Expectedly, this comes with new skills requirement on the part of the provider and most importantly the user. Postgraduate students are therefore required to upgrade their skills and practices, in order to gain awareness and take control of these technological advances.

In their study on usage of online journals at Makerere University, Kiongo-Bukenya and Nyumba (2005) revealed low usage of online journals, because of inadequate skills on use of the Internet and computer applications. Similarly, in a study aimed at examining the use of online journals, Bashorun, Isah and Adisa (2017) reveals computer illiteracy, lack of computer training and inability to retrieve particular/relevant information from various databases. Many universities do not provide end user training to postgraduate students. On the other hand, for library and information professionals' to effectively assist users in accessing online journals, they need to update their computer skills and media literacy skills. Agyekum and Ossom (2015) reveal that lack of ICT skills among library and information professionals is a major factor in assisting users to navigate the Net. More so, lack of skilled human resources to manage online journals network and technology constitute a problem. Some librarians have phobia for technology. This was confirmed by Omekwu (2004) that the conservative disposition of library staff towards the introduction and use of ICT in library and information service delivery poses a strong threat to users' satisfaction. More so, online journals are not supportive of inter library loan (ILL). Majority of online journal publishers do not allow articles from their databases to be supplied on ILL. This negates the idea of collaboration and networking associated with modern day library and information service delivery.

\section{Methodology}

This study adopted the descriptive survey design. The population of the study comprised all the ten thousand, seven hundred and seventy-five $(10,775)$ registered postgraduate students (Masters and Doctoral) in all the federal and state universities in south-south, Nigeria. The population figure was obtained from the postgraduate Admission offices of federal and state universities under study for the $2017 / 2018$ academic session. The sample size chosen for this study is 370 .The main sampling technique employed for this study was the multi-stage sampling procedure, because of the involvement of multiple sampling stages. The stages involved are as follows- Stage one is selection of Total Sample Size. The total sample size chosen for this study is 370 . This was determined based on the Krejcie and Morgan's (1970) table for determining sample size from a given population. Stage two was proportionate sampling of postgraduate students from each of the universities. The proportionate sampling technique was used to select postgraduate students for this study using the formula: SZ=NxS/P , where SZ is sample size for each university, $\mathrm{N}$ is Population in each university, $\mathrm{S}$ is total sample size and $\mathrm{P}$ is total population. Stage three was stratified sampling to reflect every characteristic in the study. The first stratum was gender- to select male and female postgraduate students. Another stratum was selected on the basis of discipline to include Sciences, Social Sciences, Engineering, Arts and Humanities. Masters and Doctoral students were already taken care of by the population. 
The instrument for data collection for this research was a self-constructed questionnaire titled: Challenges Associated with Awareness and Use of Online Journals among Postgraduate students in Universities Questionnaire (AUOJQ). The instrument was personally administered by the researcher with the help of three (3) research assistants. Copies of the questionnaire were distributed by hand to the respondents for the study in the federal and state universities under study for a period of 12 weeks. The Mean and standard deviation was used to analyze the data collected based on the research questions for the study. . The real limit of numbers was used in taking decision. Any item with mean range of 3.54.00 was considered strongly agreed. Any item with mean range of 2.50-3.49 was considered as Agreed. Any item with mean of 1.50-2.49 was considered as disagreed. Any item with mean of 0.50-1.49 was considered as strongly disagreed.

\section{Results}

A total of 336 questionnaires were retrieved making a response rate of $91 \%$.

Research Question 1: What are the challenges associated with postgraduate students' awareness and use of online journals in universities in Nigeria?

\section{Table 1 Mean responses of postgraduate students on Challenges associated with their awareness and use of Online Journals

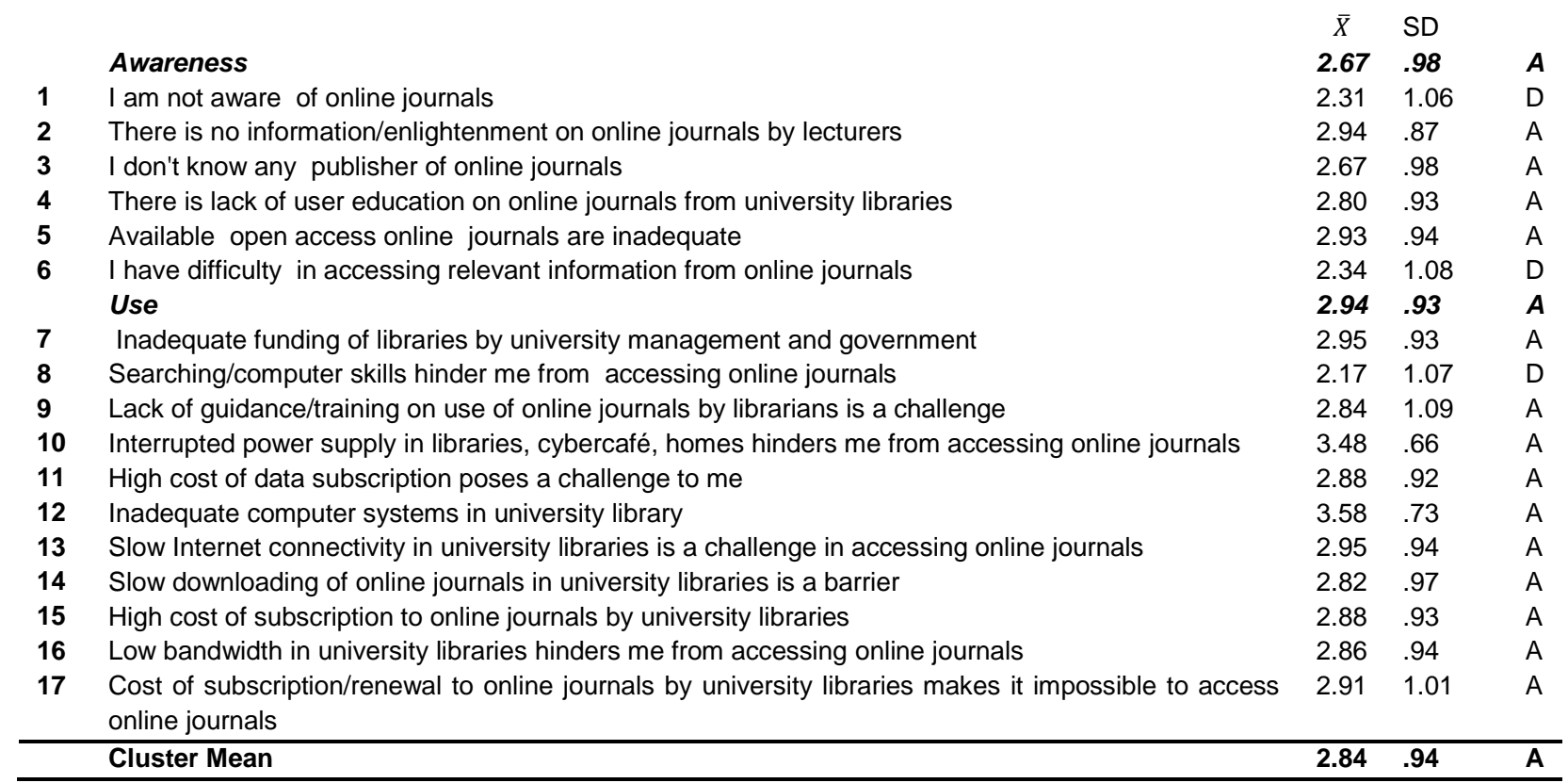

KEYS;: R=Rank ; D=Decision ; A - Agree ; SD= Standard Deviation

The data presented in Table 1 revealed the mean ratings of the responses of the respondents on the seventeen (17) challenges with the postgraduate students' awareness and use of Online Journals. Using criterion mean of 2.50 on a 4 point rating scale, the table indicates that challenges assonated with awareness that were accepted by respondents include: there is no information/enlightenment on online journals by lecturers $(\bar{X}=2.94, \mathrm{SD}=.87)$; I don't know any publisher of online journals $(\bar{X}=2.67$, $\mathrm{SD}=.98)$; there is lack of user education on online journals from university libraries $(\bar{X}=2.80, \mathrm{SD}=.93)$ and available open access online journals are inadequate $(\bar{X}=2.93, \mathrm{SD}=.94)$. On the other hand, those associated with uses that were accepted include: inadequate funding of libraries by university management and government(mean $\bar{X} 2.95, \mathrm{SD}=.93)$; Interrupted power supply in libraries, cybercafé, homes hinders me from accessing online journals $(\bar{X}=3.48, \mathrm{SD}=.66) ;$; Inadequate computer systems in 
university library $(\bar{X}=3.58, \mathrm{SD}=.73)$; Slow Internet connectivity in university libraries is a challenge in accessing online journals ( $\bar{X}=2.95, \mathrm{SD}=.94)$; High cost of subscription to online journals by university libraries $(\bar{X}=2.88, \mathrm{SD}=.93)$; Low bandwidth in university libraries hinders me from accessing online journals $(\bar{X}=2.88, \mathrm{SD}=.94)$ and Cost of subscription/renewal to online journals by university libraries makes it impossible to access online journals $(\bar{X}=2.91, \mathrm{SD}=1.01)$. See others in table 1

The overall mean score of $\bar{X} 2.84, \mathrm{SD}=.94$ showing that the respondents agreed that all the items in the cluster are challenges associated with the postgraduate students' awareness and use of online journals. The standard deviation values for the eleven challenges ranged from $\mathrm{SD}=1.01$ to $\mathrm{SD}=.66$ which implied that the respondents were not far from one another in their responses

Research Question 2: What are the strategies for enhancing the postgraduate students' awareness and use of online journals?

Table 2 Mean responses of postgraduate students' perceived strategies for enhancing awareness and use of online journals

SN STRATEGIES O OVERALL D

\begin{tabular}{|c|c|c|c|}
\hline & $\bar{X}$ & SD & \\
\hline Awareness & 3.03 & .81 & A \\
\hline Awareness campaign on online journals from university library to be carried out & 2.91 & .91 & A \\
\hline User education program on online journals to be initiated in universities & 2.99 & .86 & A \\
\hline Library orientation for all postgraduate students & 3.02 & .82 & A \\
\hline Distribution of library guides to postgraduate students & 3.08 & .76 & A \\
\hline Library tour by all postgraduate students to encourage use of online journals & 3.15 & .77 & A \\
\hline Increased enlightenment on online journals by lecturers & 3.04 & .75 & A \\
\hline Use & 3.27 & .73 & A \\
\hline Stable and strong Internet connectivity in university libraries & 3.08 & .69 & A \\
\hline Use of inverters/solar panels in university libraries & 3.31 & .75 & A \\
\hline Internet search skills training for postgraduate students & 3.35 & .75 & A \\
\hline Trained library personnel to guide postgraduate students on how to access and use online journals & 3.17 & .76 & A \\
\hline Constant subscription/renewal to online journals by university libraries & 3.53 & .68 & A \\
\hline Provision of adequate computer systems in university libraries & 3.31 & .81 & A \\
\hline Uninterrupted power supply in university libraries & 3.24 & .79 & A \\
\hline Increase in bandwidth in university libraries, cyber cafes etc. & 3.28 & .65 & $\mathbf{A}$ \\
\hline Increased funding of university libraries & 3.33 & .71 & A \\
\hline Provision of Internet facilities in university libraries & 3.30 & .71 & A \\
\hline Ensures affordable Internet by relevant agencies and government & 3.26 & 69 & $\mathbf{A}$ \\
\hline User friendly interface by online journal publishers & 3.07 & .73 & $\mathbf{A}$ \\
\hline Cluster Mean & 3.19 & .75 & $\mathbf{A}$ \\
\hline
\end{tabular}

KEYS;: VA = Very Appropriate; A=Appropriate; LA - Less Appropriate; NA =Not Appropriate; R=Rank; D=Decision ; SD= Standard Deviation

Results in table 2 shows that all the strategies mentioned for enhancing the Postgraduate students' awareness and use of Online Journals in university libraries are appropriate.

The overall mean score shows that uses strategies $(\bar{X}=3.27, \mathrm{SD}=.73)$ is greater than awareness strategies $(\bar{X}=3.03, \mathrm{SD} .81)$.The values of standard deviations of both items and the clusters show closeness meaning there is no wide variation between the respondents. In response to research question 1, on the challenges associated with awareness and use of online journals, the respondents do agree that the six and eleven challenges in this section are issues associated with "AWARENESS" AND "USE'.

\section{Discussion}

The data analysis on postgraduate students responses to research question 1 in order of priority with regards to "AWARENESS" reveals no information/enlightenment on online journals by lecturers, 
inadequate open access online journals, lack of user education on online journals from university libraries, lack of knowledge of publishers of online journals and difficulty in accessing relevant information from online journals.

With regards to "USE", response to question 1 in order of priority reveals inadequate computer systems in university libraries, interrupted power supply in libraries/cybercafes, slow internet connectivity in university libraries, inadequate funding of libraries by government and university management, high cost of subscription/renewal to online journals by university libraries, high cost of data subscription, low bandwidth in university libraries, lack of guidance/training on use of online journals by libraries and slow download of online journals in university libraries.

Buttressing the findings of this research, Trivedi and Joshi (2009) identified poor Internet connectivity, epileptic power supply and high cost of Internet access as major challenges confronting postgraduate students' use of online journals. Similarly, Agyekun and Ossom (2015) identified slow internet connectivity, frequent power outage and lack of proper search strategies as some of the challenges associated with using online journals. There is no doubt that these challenges fall within the spectrum of 'USE'. Bashorun, Isah and Adisa (2011) gave lack of awareness about online journals provided by the library as well as ineffective channels of communication in campuses as challenges associated with online journal use.

On strategies to enhance postgraduate students' awareness and use of online journals in university libraries, the respondents agreed that increased enlightenment on online journals by lecturers, library tour by postgraduate students to encourage use of online journals, library orientation program for all postgraduate students and user education program by universities are the major strategies to enhance awareness of online journals in universities. To enhance the use of online journals, respondents agreed that constant subscription/renewal to online journal database by university libraries, increase funding of university libraries, provision of adequate computer systems in university libraries, increase in bandwidth, use of inverter/solar panels and Internet search skills training for postgraduate students among others are the major strategies to enhance use of online journals by postgraduate students in universities in south south, Nigeria.

The findings of this study as stated above lends credence to Amughoro, Makgahlela and Bopape (2015) which pointed out that orientation and training on the use of electronic resources should be carried out from time to time especially for newly registered postgraduate students by the university library. The place of training and re-training in this regard cannot be over-emphasized. This is so important, because computer skills, information literacy skills, among others, are required to navigate the Internet and retrieve relevant information from online journal databases. Online journal database and Internet searching is highly language dependent; so much attention has to be paid to terminology (Nwalo, 2000).

\section{Conclusion}

The study investigated challenges associated with awareness and use of online journals among postgraduate students of universities in south-south, Nigeria. 2 research questions were raised for the study which adopted the descriptive survey design. The population of the study comprised 10,775 respondents who are registered postgraduate students in federal and state universities in south-south Nigeria. A total of 370 postgraduate students were chosen as sample size for the study. Mean and standard deviation were used to answer the research questions. The major findings of the study were identified to include absence of enlightenment on online journals by lecturers, lack of knowledge of publishers of online journals, lack of user education on online journals from university libraries and inadequate open access online journals. Respondents in the study proffered several strategies for enhancing awareness and use of online journals. They include, user education on online journals by 
university libraries, increase enlightenment on online journals by lecturers, internet search skills training for postgraduate students, increase in funding of university libraries by management and constant subscription/renewal to online journals by university libraries.

\section{Recommendations}

Based on the findings, the study recommends as follows:

1. University libraries should embark on capacity building initiatives such as training exercise to re-train librarians/library officers on effective online search strategies and information retrieval techniques. This is to build the knowledge base of librarians to be able to provide relevant guidance to postgraduate students on how to access and use online journals. This can be in form of in-house training, at no cost to the library.

2. University libraries should install inverter/battery system and or solar panels in libraries to ensure regular power supply. This project can be financed with TETfund intervention project fund. This will aid uninterrupted access to online journals by Postgraduate students on campus.

3. The cost of data plan and bundle by Internet service providers should be reduced particularly for postgraduate students to enable them use online journals at little or no cost. The Nigerian Communication Commission should enforce this as the regulatory agency in charge of voice, data and satellite communication in Nigeria.

4. University libraries should engage on aggressive awareness campaign on online journals and their usefulness for effective research in universities. Such awareness about online journals should draw attention to subscription based and available open access journal platforms. This should be made a regular feature through seminars, design and distribution of fliers in classes and other avenues, orientation exercise for postgraduate students to enhance their awareness and subsequent use of online journals.

\section{References}

Agu, N. \&Oluwatayo, G.K. (2014). Variables attributed to delay in thesis completion by postgraduate students. Journal of Emerging Trends in Educational Research \& Policy Studies, 5 (1), 6-12.

Agyekum, B.O. \&Ossom, S. (2015). Awareness and impact of electronic journals usage by faculty members and lecturers in Kumasi Polytechnic, Ghana.Information and Knowledge Management, 5 (1), 9-17.

Ali, P.M. \& Nisha, F. (2011). Use of e-journals among research scholars at central science library, University of Delhi, Collection Building 30 (1),.53-60.

Amughoro, F. A, Makgahlela, L \& Bopape, S (2015). The use of electronic information resources for academic research by postgraduate students of Delta State University, Abraka, Nigeria. South Africa Journal of Libraries and Information Science

Anckar, B. \& Walden, P. (2001).Selfbooking of high \& low-complexity travel products: $\quad$ Exploration findings. Information Technology \& Tourism, 4(3\&4), 151-165.

Bashorun, M.T.,Isah, A. \&Adisa, M.Y. (2011). User perception of electronic resources in the university of Ilorin, Nigeria. Journal of Emerging Trends in Computing \& Information Science, 2(11), 554-56.

Borrego, A .(2010).Analysis of the behaviour of the users of a package of electronic journals in the field of chemistry. Journal of Documentation, 63, 243-258.

England, R. (2013). An investigation into the move towards electronic journals: A case study of NHS libraries in Kent, Surrey and Sussex. Health Information \& Library Journal, 30: 241-244. 
Gakibayo, A., Ikoja-Odongo, J.R. \&Okello, O, C. (2013).Electronic information resources utilization by students in Mbarara University library.Library Philosophy \& Practice. Retrieved from https://digitalcommons.unl.edu/libphilprac/869

Gbaje, E. S.(2007). Provision of Online Information Services in Nigerian Academic Libraries. Nigerian Libraries, 40(2), 32:47.

Kiongo-Bukenya \& Nyumba, L (2005).Utilization of electronic information resources by academic staff at Makerere University. University of Dar es Salaam Library Journal 6(1). 18-28

Krejcie, R. \& Morgan, D. W (1970). Determining sample size for research activities. Educational and Psychological Measurement, 16, 14-23

Manda, P.A. (2005). Electronic resources usage in academic and research institutions in Tanzania.Information Development, 21 (4), 38-48.

Nwalo, K.N (2000) Collaboration in the provision and utilization of IT facilities for library and information science education in Nigeria.Paper presented at 10th Biennial Conference of the National Association of Library and Information Education NALISE: Ibadan.

Omekwu, C.O (2004). Planning for Library and Information Center computerization in

Developing countries management and services. Ibadan: Eni Coleman Publications

Panda, K.C. \&Mohanta, R. (2008).Role of E-Resources in information Retrieval. In: C. Lal, (ed.) Information Literacy in the Digital age. New Delhi: Ess Pub, 88 - 101

Reitz, J. M (2004). Dictionary for library and information science. London: Libraries Unlimited

Sharma, C. (2009) Use and impact of e-resources at Guru Gobind Singh Indraprastha University (India): A case study. Electronic Journal of Academic and Special Librarianship,10(1),1-8.Retrieved from http://southernlibrarianship.icaap.org/content/v10n01/sharma_c01.html

Thong, J.Y.L., Hong, W.I. \& Tam, K.Y. (2004). What leads to user acceptance of digital libraries.Communication of the ACM, 47(11), 78-83 